\title{
Hwaetberht, Sicgfrith and the Reforming of Wearmouth and Jarrow
}

Abstract: This paper builds upon recent scholarship, exploring how Wearmouth-Jarrow, founded as a 'family monastery' in the mainstream of early medieval Northumbrian monasticism, reformed itself to become the proto-Benedictine bastion of correct behaviour described in Bede's Lives of the Abbots and the anonymous Life of Ceolfrith. The understudied abbots Hwaetberht and Sicgfrith appear to be at the heart of this process. Their careers and actions suggest the existence of a party at Wearmouth-Jarrow opposed to the dominance of the founder's kin-group and wishing to reform the monastery on Benedictine lines. This party triumphed only in 716, when Hwaetberht became abbot.

We probably know more about Wearmouth-Jarrow than any other monastery from the Northumbrian 'Golden Age'. That is partly because of the hugely important archaeological excavations which took place at the sites of both St Peter's, Wearmouth, and St Paul's, Jarrow, during the last century; ${ }^{1}$ but a surprising number of texts concerning the foundation of the monastery and the lives of its early abbots have also survived which provide an insight into the first stages of Wearmouth-Jarrow's history. Best known is the Historia abbatum of Wearmouth-Jarrow's most famous son, Bede. Alongside this one can set his homily on Wearmouth's founder Benedict Biscop (Homily I.13) and the anonymous Vita Ceolfridi, detailing the life of Biscop's successor. ${ }^{2}$ Such a wealth of written material does not exist for any other early Anglo-Saxon house, but it has created its own challenges for interpreting the early history of Wearmouth and Jarrow.

In the last century the written sources for Wearmouth-Jarrow became the basis for an argument which presented the monastery as one which was outside the mainstream of 
Northumbrian aristocratic monasticism, indeed as a 'counter-cultural' institution. ${ }^{3}$ In Northumbria, as elsewhere in the early medieval West, the asceticism of the desert fathers had compromised to a large extent with the native elites whose spiritual and material interests monasticism increasingly served. Irish, Frankish and Anglo-Saxon society all contained religious houses founded by aristocratic families who had a natural interest in retaining some sort of control over the property of those establishments in future generations; in many cases the early abbots or abbesses of a house would all come from a single kin-group. ${ }^{4}$ But Wearmouth's founder, Benedict Biscop, was famously described as refusing to allow his brother succeed him as abbot - at Biscop's monastery the spiritual family was to be given priority over the biological one. ${ }^{5}$ Bede's homily on Biscop chose to emphasize this idea of the brethern as their founder's spiritual children, for whom he had chosen to reject the opportunity of having children according to the flesh; ${ }^{6}$ the anonymous biographer of Ceolfrith similarly stated that blood relationships were less important than spiritual ones when deciding who would succeed Biscop. ${ }^{7}$

Patrick Wormald powerfully argued that this rejection of the kin-group, in marked contrast to much of the monasticism of the time, appeared in the Wearmouth-Jarrow texts because it had formed part of the founder's ideology. ${ }^{8}$ Bede had quoted Biscop as citing the Benedictine Rule's prescriptions for free abbatial elections upon his deathbed and Wormald proposed that, while Wearmouth-Jarrow had certainly not been founded as a Benedictine house, Benedict's regula was nonetheless an important element in Biscop's monastic vision. ${ }^{9}$ Henry Mayr-Harting subsequently built upon these insights, portraying Biscop's foundation as a monastery where the Benedictine attempt to strip the inmates of the distinctions of class and kin-group formed a particularly important part of the community's identity. ${ }^{10}$ In other words, Wearmouth-Jarrow was a religious community self-consciously 
opposed to the compromises with the world which marked so many similar early medieval religious foundations, especially those lacerated in Bede's letter to Bishop Ecgberht of York in $734 .^{11}$

Recently however, a radical re-reading of the key sources has overturned many aspects of this interpretation. The work of lan Wood, undertaken in preparation for a new edition and translation of the texts, has carefully and on the whole convincingly read the Historia abbatum and the Vita Ceolfridi against the grain. ${ }^{12}$ These are not windows, allowing us to peer clearly into Wearmouth-Jarrow's origins, he suggests, but distorting lenses, intended to present a particular image of the monastery to suit the ideology of the authors - and not that of the earliest abbots. The sources go to such trouble to emphasize the unity of the two houses at Wearmouth and Jarrow, declaring them to be 'one monastery in two places', not because this was obviously true, but precisely because it was fiercely contested. ${ }^{13}$ Similarly, Wood has argued, the issue of family was not as straight-forward as the texts try to make it appear; rather than rejecting the model of the family monastery which he saw all around him, Benedict Biscop may in fact have accepted it and established a thoroughly mainstream monastery. $^{14}$

After all, he clearly appointed his own cousin Eosterwine to act as his deputy at Wearmouth - Biscop was by no means opposed to having members of his kin play important roles at his monastery, even if Bede in particular sings Eosterwine's praises so highly as to leave no room for doubt that he was the right man for the job. ${ }^{15}$ In fact, Biscop's kin seems to have had control over the community from its foundation until 716 , a period of well over forty years. At stake here is the question of Biscop's relationship with his eventual successor, and one-time assistant, Ceolfrith. The latter originally came to Wearmouth to help its founder 
from Wilfrid's community at Ripon, before becoming the first abbot of Jarrow and then, eventually, the joint abbot of Wearmouth and Jarrow in 690, appointed as such by Biscop on his deathbed. ${ }^{16}$ This appointment, of course, seems to give the lie to Biscop's assertion that his successor could only be chosen by a free election as per the Benedictine Rule, though both Bede and Ceolfrith's biographer tempered Biscop's authority here by suggesting that the community approved of his actions. ${ }^{17}$ Furthermore, both authors went to some trouble to state that Biscop was never influenced by family feeling when selecting Ceolfrith.

Bede asserted that Ceolfrith was 'a man close to [Biscop] not so much because they were related as because they shared the same upright character'; ${ }^{18}$ the author of the Vita Ceolfridi declared that Ceolfrith 'was joined to [Biscop] more by spiritual than by fleshly kinship ${ }^{\prime 19}$ For the editors of the new edition of these texts, as well as for their nineteenthcentury predecessor Charles Plummer, the implication of such statements is fairly clear: Ceolfrith and Biscop were kinsmen. ${ }^{20}$ It should be said that Wormald and Mayr-Harting were not convinced of this, and even in English both statements retain the ambiguity contained in the Latin. ${ }^{21}$ Did the two authors contrast Biscop's blood-relationship with Ceolfrith (which he set at naught) with his spiritual bond (which was all important)? Or did they celebrate the fact that Biscop chose Ceolfrith despite the lack of any kinship between them? There were surely more straightforward ways of saying the latter. The Latin seems, almost deliberately and tortuously, to try to both acknowledge the family link and dismiss it. If there were no such kinship, it seems strange that the texts would have felt the need to make the point that it was unimportant when Biscop made his decision.

This is a point of great significance for the early history of Wearmouth-Jarrow, for if, as seems to be the most reasonable interpretation of the sources, Ceolfrith was not only 
appointed by Biscop as his successor but related to him also, then the monastery in its early days appears little different to those aristocratic communities which Bede declared were in desperate need of reform when writing to Bishop Ecgberht in $734 .^{22}$ In fact it only seems to be with Ceolfrith's resignation in June 716 that Wearmouth-Jarrow was 'reformed' along more Benedictine lines. Ceolfrith, having decided to spend his final days in Rome, left the monastery without choosing a successor, providing the opportunity for the monks themselves to elect Hwaetberht as the new abbot. We have no evidence to suppose that Hwaetberht was a member of the founder's kin and he therefore appears to be the first abbot of Wearmouth and Jarrow to have been freely elected, according to the Benedictine Rule and without consideration of his relationship to Benedict Biscop. ${ }^{23}$ If, as seems likely, Bede and the anonymous author started to pen their texts shortly after Hwaetberht's election, both can be seen as attempting to shore up the authority of the new dispensation by successfully re-writing the monastery's history to match present circumstances. ${ }^{24}$

Such an interpretation may on reflection seem rather problematic since the sources make it clear that Hwaetberht was not actually the first abbot of Wearmouth to be elected. On Biscop's sixth visit to Rome (circa 684), his cousin and deputy, Eosterwine, died of the plague and was replaced by a monk called Sicgfrith, apparently chosen by his brethren within the community. As with Hwaetberht, Sicgfrith appears to have been unrelated to Biscop himself, though this assumption is as much based on the sources' silence as anything else - in fact, the sources say very little at all about Sicgfrith. ${ }^{25}$ Ian Wood has, however, pointed out that William of Malmesbury (writing of course at a remove of many centuries) seems to suggest that Biscop accepted Sicgfrith as his deputy upon his return to England only with some unease. ${ }^{26}$ Certainly, he never allowed his monks any vote in the appointment of the previous co-abbots Ceolfrith and Eosterwine, and it seems hard to 
disagree with Wood's contention that Sicgfrith was in effect a blip in the otherwise smooth dominance over the monastery which Biscop and his relatives enjoyed from its foundation until 716. He argues that change finally came about because Ceolfrith was in favour of the Benedictine-leaning ideas which inspired the elections of both Sicgfrith and Hwaetberht indicated by the comments of Bede and Ceolfrith's biographer that as abbot of Jarrow he had approved Sicgfrith's election at Wearmouth in Biscop's absence. ${ }^{27}$

However, there seems to be more one can say about Sicgfrith and his relationship with the later developments at Wearmouth-Jarrow. While the textual accounts of the monastery's early history do not say an awful lot about him, it is nonetheless clear that he loomed large in Hwaetberht's vision of the community's past. Shortly after his election as abbot, Hwaetberht staged a ritual to underpin his new authority and represent the continuity between his rule and that of Biscop and his deputies. Eosterwine and Sicgfrith's relics were translated into a new grave, right beside that of Biscop in the church of St Peter at Wearmouth. In part this may have been a response to the possible trauma of Ceolfrith's resignation and his stated intention of dying in Rome. The community was thereby denied the relics of the man who had ruled it with distinction for over twenty-five years (and even longer at Jarrow); Hwaetberht's actions emphasized that nonetheless the monastery still possessed the bodies of saintly abbots who could act as heavenly patrons. ${ }^{28}$ Alongside this aim, however, there seems to have been another purpose behind the ceremony, one which focused on Sicgfrith in particular.

It is worth looking at Bede's description of the translation in some detail:

He removed the bones of Abbot Eosterwine, which had been laid in the porch at the entrance of the church of the blessed apostle Peter, and also the bones of Abbot 
Sicgfrith, once his teacher, which were buried outside, to the south of the sacristy, and placed both men's bones in a single chest with a central partition. He placed this inside the church, beside the body of the blessed father-abbot Benedict. He did these things on the anniversary of Sicgfrith's birthday ... ${ }^{29}$

The first point of note is that Bede establishes a direct personal link between Hwaetberht and Sicgfrith: a pupil-teacher relationship. In a monastic context this probably signified a lot more than that Sicgfrith had taught Hwaetberht his Latin grammar, important as that undoubtedly was. Byrhtferth of Ramsey, in the Historia regum ascribed to Symeon of Durham, catches something of what this probably meant when he described Hwaetberht as Sicgfrith's 'disciple'. ${ }^{30}$ Monastic education was as much about the shaping of the entire person as it was about passing on information; the teacher was themselves the lesson, a lesson in how to live the religious life, which the student had to learn through carefully imitating the master's practice. ${ }^{31}$ Hwaetberht joined Wearmouth-Jarrow at a young age: he was probably therefore an oblate, sitting at the feet of Sicgfrith and modelling himself upon the latter at an early stage in his life. ${ }^{32}$ This is a strikingly significant relationship for two monks to have whose careers were so trail-blazingly similar, both having been elected to the abbacy without any apparent link with the founder's kin-group.

It seems therefore all the more significant that Hwaetberht chose to stage the translation on Sicgfrith's dies natalis. Despite the language of the recent translation, Bede obviously did not speak here of the late abbot's literal birthday, but of the day on which he was (re)born in heaven through death. ${ }^{33}$ If by translating his relics Hwaetberht wished to establish Sicgfrith as a saint, then he was also choosing to effectively consecrate Sicgfrith's feast day at the same time. ${ }^{34}$ Perhaps the date of the translation is a partial coincidence: perhaps 
Sicgfrith's feast was simply the first significant date arising after Hwaetberht had decided to move the relics of the old abbots - in which case it could be that the apparent emphasis on Sicgfrith (rather than any of the other deceased abbots) is accidental. Proving this either way seems impossible, but, considering the link between Hwaetberht and Sicgfrith and the fact that Bede felt the date worthy of record, the suggestion that this date may have been deliberately chosen is plausible. Choosing Sicgfrith's feastday for the ceremony necessarily foregrounded his sanctity.

The possibility of the centrality of Sicgfrith's posthumous reputation to the translation should make us reflect upon what Bede had to say about where the relics of the different abbots lay. Biscop's remains were not actually translated at all, remaining where they had been placed at his death (almost certainly according to his own wishes) in the most honourable location in the monastery: beside the altar within St Peter's, in sight of the holy relics which Biscop himself had brought from Rome to Northumbria: an unsurprising location for the founder of the community. ${ }^{35}$ Eosterwine's body lay in the entrance to the church, within the porticus which lay before the main body of St Peter's; in other words, Biscop's deputy rested in a place of distinct honour though one clearly secondary to that of Biscop himself. Eosterwine had been buried somewhat removed from the liturgical heart of the monastery but in a place which recalled the burial location of the bishops of Rome, in front of St Peter's. ${ }^{36}$ Bede went on to imply that Sicgfrith had been buried in a third location: foris sacrarium ad meridiem.

Grocock and Wood's recent translation is quite blunt: Sicgfrith is described as having been buried 'outside', foris being taken to imply that Sicgfrith was out of doors, in the open air. Previous translations have taken a rather more ambiguous approach, merely implying that 
the abbot had been buried outside (and on the south side of) the sacrarium (translated as either sacristy or sanctuary, though occasionally it does mean cemetery also). ${ }^{37}$ The difference is surely an important one: if Sicgfrith were buried out of doors before 716 then his relics lay in an entirely different context from those of Biscop and Eosterwine. Whilst their tombs must have formed part of the daily liturgical round of the Wearmouth brethren, sharing in the dignified romanitas of the church of St Peter, Sicgfrith's would have been separated from the community's heart, lying amongst the mass of the monastic dead. ${ }^{38}$ The south side of the altar does seem to have been a popular spot for saintly shrines, with Aidan, Cuthbert and Wilfrid all interred in such locations, though Thacker has argued that Wearmouth seems to be an 'important exception' to this trend, with Biscop being buried to the east of the altar. ${ }^{39}$ If Sicgfrith were indeed buried outside St Peter's, in the cemetery, then a translation would have been essential to 'make' him a saint since his original burial had done nothing to suggest that he enjoyed any such status. ${ }^{40}$

Since Sicgfrith predeceased Biscop, it would seem likely that the latter played an important role in deciding the location of his deputy's burial. ${ }^{41}$ That location is surely significant, therefore, as evidence of how Biscop wanted Sicgfrith to be remembered within the monastery which he had founded. Even if the interpretation of Bede's account presented above is wrong and Sicgfrith was buried, as has been hinted at in some scholarship, within a porticus lying on the south side of St Peter's, the implication of Bede's text remains that before 716 there was a clear hierarchy in the positioning of the relics of Wearmouth's abbots. $^{42}$ The three different locations for the three different abbots, with the central focus being on the founder and secondary attention directed to his kinsman, suggests something about the officially promulgated identity of the monastery before Hwaetberht became 
abbot. The peripheral location of Sicgfrith's body made physically clear his peripheral status within a house controlled by the kin of Benedict Biscop.

The translation of 716 destroyed the hierarchy of honour which had previously framed the abbots' relics; now, Sicgfrith and Eosterwine were placed within a single coffin, implicitly made equal as Biscop's two deputies, issues of blood and election deemed irrelevant. This coffin was then interred beside that of Biscop within St Peter's, emphasising the monastery's devotion towards all its former abbots whether they belonged to the founder's kin or not. By such an action Hwaetberht appears to have inaugurated the history of the abbey which the surviving written texts present and, possibly, in the process erased an older tradition of commemoration at Wearmouth, one which had derived from its days as a family monastery and which had side-lined Sicgfrith. Hwaetberht's ceremony honoured all of the community's abbots, but by honouring them all equally may nonetheless have been a silent riposte to Biscop. The translation made a dramatic break with the past, intended to be just as much a 'deliberate refashion[ing] of Wearmouth-Jarrow's memory' as the Historia abbatum and Vita Ceolfridi. ${ }^{43}$

A story Bede goes on to tell does complicate this reading of his description of the translation. By miraculous coincidence, on the same day as Hwaetberht moved the old abbots' relics, the monk Witmer died and was then buried, as seemed only appropriate, in 'the place where the above-mentioned abbots had earlier been interred'.$^{44}$ In loco-Bede here spoke as if Eosterwine and Sicgfrith had been buried in a single location and that there was only a single grave open into which Witmer could be placed. It is hardly special pleading to suggest that this is as likely to be a simple unthinking slip on Bede's part as evidence 
devastating to the above theory; but it is nonetheless salutary to remind ourselves upon what fragile foundations our theories about Wearmouth-Jarrow's internal politics must rest.

To what does the evidence sketched out above amount? Most importantly it suggests a strikingly close connection between the first two abbots of Wearmouth-Jarrow to genuinely depend upon a Benedictine-style approach to abbatial election and to come from outside the kin of Benedict Biscop. It suggests a continuity, one which was genuinely felt and perceived at the time, between Sicgfrith and Hwaetberht. By placing Sicgfrith beside Biscop in St Peter's church, Hwaetberht was obviously shoring up his own authority as an abbot not of Biscop's kin. He could have been honouring a beloved master, righting what he may have seen as an historic wrong directed towards a former abbot with whom he had a personal relationship. But his actions could also have been a triumphant celebration of the victory of the ideals which Sicgfrith represented, ideals which probably were championed by a persistent party within the monastery which had once brought Sicgfrith to power and had now, more conclusively, established Hwaetberht as leader.

Thinking about the connection between these two monks in this way, as both members of a particular 'party' within Wearmouth-Jarrow's internal politics, is potentially fruitful. ${ }^{45}$ Similarities in how our texts describe both Hwaetberht and Sicgfrith ought to be noted. In particular both are described as being particularly learned, with a bookish character clearly suggested: 'Sicgfrith was a well-taught man in knowledge of the Scriptures'; ${ }^{46}$ Hwaetberht not only had followed the monastery's rule from his earliest days 'but had also been occupied in working hard at writing, singing, reading, and teaching'. ${ }^{47}$ The latter comment is strikingly similar to Bede's famous description of himself at the end of the Historia ecclesiastica. ${ }^{48}$ His own talents for scriptural interpretation, as the author of well over a 
dozen works of exegesis, hardly need to be mentioned and the fact that Bede's writings provide some of the strongest rhetoric in defence of the primacy of the spiritual over the biological family at Wearmouth-Jarrow seems significant. ${ }^{49}$ If there were a party at the monastery opposed to the institutional dominance of the founder's family then Bede, whose writings reveal a deep respect for the Benedictine Rule, was certainly a member. ${ }^{50}$ Interestingly, Witmer, the monk who Hwaetberht honoured by burying in the tomb (or one of the tombs?) left free by the translation of the old abbots, is also described as having been learned in scripture: 'a man as learned in the knowledge of worldly subjects as of the Scriptures'. ${ }^{51}$ This may not seem particularly striking a fact - after all it might be assumed that monks at Wearmouth were quite au fait with the Bible as a matter of course. Certainly Hwaetberht and Bede, having been raised from a very early age within the monastery, are likely to have been saturated in exegetical and biblical learning. Witmer however joined the monastery when he was already quite mature (ueteranus Bede says), bringing a ten-hide estate with him that he had received from King Aldfrith. ${ }^{52}$ These facts suggest that Witmer was a retired king's thegn, as Biscop and Eosterwine had been. But those important figures in the monastery's history never appear to have been praised for their scriptural learning. ${ }^{53}$ The picture of Eosterwine painted by Bede is of a startlingly humble and hardworking monk, but not of a particularly learned one - we see Eosterwine 'in the bakehouse, in the garden, in the kitchen', but not in the scriptorium. He spent his time in 'guiding the progress of the plough with its handle, or shaping iron with a hammer, wafting the winnowing-fan with his hand, or doing something else of the sort', not in singing, writing and teaching as Bede and Hwaetberht did. ${ }^{54}$ Modern historians have been prone to calling Biscop a 'scholar', but yet the sources never actually describe him as being an expert in biblical learning. ${ }^{55}$ Certainly 
Biscop had a passion for buying books; but he would not have been the first or last aristocrat to gather an extensive library for which he never personally had much use. Wearmouth's founder's knowledge, his learning, was clearly of monastic practice learnt at first hand, rather than scholarly wisdom mined from books. ${ }^{56}$ It is not implausible, considering their early careers in royal service, that Eosterwine and Biscop may have come to the regular life a little too late to become exegetes of any note. The fact that Witmer, apparently from a similar background, was scripturarum scientia eruditus seems noteworthy then.

Might scriptural learning be a code in the sources, a badge of membership of the party to which Hwaetberht, Sicgfrith and Bede belonged? Certainly something made Witmer significant to the community at Wearmouth-Jarrow after 716 as Bede named him twice in the Historia abbatum, for reasons which are not particularly clear. ${ }^{57}$ His land may have been especially important to the monastery and certainly the fact that it is named along with the donor suggests that the community may have wished to make particularly secure their claim to it; ${ }^{58}$ nonetheless, Hwaetberht's decision to particularly honour him in death suggests some especial link between the two monks and a desire by the new abbot to celebrate Witmer and give him an important place in the community's memory. The claim that Witmer was the imitator of the old abbots situates him within an ongoing tradition of the monastery's life, while neatly side-stepping the fact that he had only entered WearmouthJarrow after the deaths of Biscop, Eosterwine and Sicgfrith. ${ }^{59}$ Witmer's burial might have been another move to put the 'anti-family' party at the heart of the monastery's history, by throwing up a bridge between the old and the new and by emphasising their ability to contribute to the material wealth of the community. 
None of this is to say that the allusions to scriptural learning on the part of Sicgfrith, Witmer or Hwaetberht are meaningless. Bede undoubtedly was exceptionally learned in the scriptures and their interpretation, but he was not the only one with such interests at his monastery. Hwaetberht actually appears to have played quite an important part in the venerable exegete's career and one which probably deserves more recognition and analysis. The first commentary Bede ever wrote, the Explanatio apocalypseos, is dedicated to Hwaetberht (under his nickname Eusebius), who seems to have in turn been responsible for bringing this work and its author to the attention of Acca of Hexham, Wearmouth's diocesan bishop from $710 .^{60}$ Acca was to become Bede's major patron throughout his career, providing him with a backer from outside the monastery whose authority over clerics throughout his diocese may have played an important role in bringing the monk's work to a wide audience. ${ }^{61}$ Hwaetberht's role as facilitator in bringing such a productive relationship about should not be forgotten, not least because it shows that Hwaetberht was in communication with the man who would consecrate him as abbot of Wearmouth-Jarrow in 716 years before this was to happen. ${ }^{62}$

Hwaetberht continued to be personally interested in Bede's work after becoming abbot since the latter dedicated the great computistical treatise De temporum ratione to him in 725. ${ }^{63}$ Some evidence exists that Hwaetberht himself dabbled in scholarship: the riddlecollection called the Aenigmata Eusebii. ${ }^{64}$ This is one of an established genre of Anglo-Latin riddle collections which emerged from a monastic context in the early Middle Ages; Aldhelm, Boniface and the archbishop of Canterbury Tatwine, all contributed to the tradition. ${ }^{65}$ No definite proof exists that the Eusebius of the riddles was Eusebius of Wearmouth, but the name is unlikely to have been a very common one in Anglo-Saxon England and there is certainly nothing in the work condemnatory of an ascription to 
Hwaetberht. ${ }^{66}$ The riddles show the marks of what we might think of as a classic monastic education: Eusebius was well-read in the Bible and in Isidore of Seville; ${ }^{67}$ but he also may well have had access to Aldhelm's verse, Pliny and some basic Greek - all of which he could have picked up at Wearmouth-Jarrow. ${ }^{68}$

More unusually, the riddle-writer had an excellent command of computus. The Aenigmata Eusebii are unique amongst Anglo-Latin riddles in containing riddles dedicated to computistical subjects: the leap of the moon and the bissextile year. ${ }^{69}$ Considering Wearmouth-Jarrow's reputation as a centre of computistical science and Bede's choice to dedicate De temporum ratione to Hwaetberht, this seems highly significant. ${ }^{70}$ If the riddlewriter were Hwaetberht then it would appear that he was not quite as good a poet as Bede himself, but he was clearly the product of a solid monastic education of which he had no reason to be ashamed. ${ }^{71}$ Even the nickname Eusebius suggests a rather intellectual milieu for Hwaetberht. It is Greek of course, self-consciously learned therefore: the kind of name which the oblates who made the most use of Biscop's library might have enjoyed to give to one of their own number. It symbolized the monk's religious zeal, appropriate therefore for one of those brothers aiming to bring the monastery in line with Benedictine and highminded spiritual values. ${ }^{72}$

Based on this kind of evidence, what might we suggest about Wearmouth's 'anti-family' party? It probably was drawn, to a large extent, from the monastery's oblate community. Even if many of those who joined the monastery as children were related to the founder and his kin (as has been suggested of Bede), they still formed a group more likely to identify with the monastery itself as a community than just with the founder's family. ${ }^{73}$ Early medieval oblation often derived its strength from ongoing ties between the world and the 
cloister, of course, but oblates still look like good candidates for the champions of free, internal abbatial elections. ${ }^{74}$ That a self-conscious air of intellectualism may have hung over such a group seems, once again, highly plausible considering the likely educational environment in which its members would have been raised. For many such individuals the intense inter-generational bonds which exist in biological families might easily have been replaced by the pupil-teacher bond.

The evidence presented here suggests that a distinct party existed within WearmouthJarrow for many years through the late seventh and early eighth centuries, a party committed to the ideals whose triumph we now see reflected within the post-716 sources for the monastery's history. The important work of recent years on these sources raised the question of how Wearmouth-Jarrow reformed itself, how did it move from being the religious foundation of Benedict Biscop to be being a radically anti-family, proto-Benedictine monastery? I have here suggested that central to this process might have been, not Ceolfrith's own leanings towards free abbatial election as recently suggested, but the efforts of Sicgfrith, Hwaetberht and others like them. ${ }^{75}$ Bede and Ceolfrith's biographer took care to state that Ceolfrith had supported the election of Sicgfrith in $685 / 6$, perhaps from a concern to rubberstamp the aging, and known to be dying, Ceolfrith's acceptance of Hwaetberht's election in $716 .^{76}$ Certainly the abbot's decision on the later occasion to leave the monastery before the vote had taken place seems like a rather theatrical move to leave no doubt that the decision rested with the brethren and not with the abbot. ${ }^{77}$ One wonders whether Ceolfrith would have been as content to leave Wearmouth-Jarrow had the result of the vote seemed likely to be inconclusive. ${ }^{78}$ 
None of this is to suggest that other factors did not play a role in Ceolfrith's resignation.

Bede's comments from the time suggest that Ceolfrith's departure was sudden, unexpected and upsetting; ${ }^{79}$ political changes in Northumbria with the death of King Osred in 716 may well have played a role in the timing of the resignation. ${ }^{80}$ Bede's commentary On 1 Samuel, which he was writing at the time and which deals in part with the death of King Saul, may reflect, it has been suggested, possible concerns about political crisis at Wearmouth-Jarrow at this time.$^{81}$ However, none of the exegetical comments Bede makes suggest any great upheaval following the death of a contemporary king. ${ }^{82}$ The 'anxiety of mind' which descended upon Bede and the 'dismay' felt by the monks as a result of Ceolfrith's speedy departure need not indicate that plans for the succession had not previously been discussed, merely that the exact circumstances in which they were enacted were unexpected. Bede's contemporary account of the perturbation caused by Ceolfrith's resignation is rhetorically structured to emphasize the restoration of tranquillity and order through God's appointment of Hwaetberht. ${ }^{83}$

The length of Ceolfrith's tenure as abbot made the hour of parting a genuinely emotional event for the community at Wearmouth and Jarrow, but it also makes it unlikely that thoughts had not begun to turn to how the aged Ceolfrith would eventually be replaced. Hwaetberht in many ways was the perfect candidate for abbot: Sicgfrith's student had visited Rome on monastic business, giving him the important cultural capital which Biscop and Ceolfrith had also possessed. ${ }^{84}$ On that occasion, he had helped carry back to Jarrow a papal privilege which confirmed the monastery's right to elect its abbot, bearing, therefore, the papyrus whose authority would underwrite the legitimacy of his own election. ${ }^{85}$ Calling him Eusebius, his friends emphasized his clear religious credentials for the job; a pre-existing relationship with Wearmouth's local bishop based around common scholarly interests can 
hardly have been a disadvantage, certainly not when Acca was invited to the monastery to consecrate the new abbot. Nonetheless, Hwaetberht took no chances with his election. He immediately followed Ceolfrith in order to gain his personal approval as abbot, perhaps deliberately modelling himself on his master Sicgfrith whose election was similarly approved by Ceolfrith - or was Hwaetberht's election the model for how Sicgfrith's was remembered? Regardless of the exact details of what happened in June 716, probably lost irrecoverably, the outlines suggest that Hwaetberht was a consummate monastic professional. The history of Wearmouth and Jarrow has tended to focus upon the great, heroic figures of Biscop, Ceolfrith and Bede; but Hwaetberht clearly played an important role in shaping the development of the monastery and in changing the focus of its memories. ${ }^{86}$ In the history which he sought to promote Sicgfrith clearly played an essential role, equal to that of Eosterwine and possibly even the community's founder himself. Little detail survives about either Hwaetberht or Sicgfrith, but just enough to give us some hint of the flesh and blood men who lived within and sought to reform and reshape Biscop's monastery. The recent work on the origins of Wearmouth and Jarrow has changed how we think of those houses' most famous abbots; it may also provide the opportunity to change our ideas about some of their less appreciated colleagues. ${ }^{87}$ 
${ }^{1}$ R. Cramp et al., Wearmouth and Jarrow Monastic Sites, 2 Vols (Swindon, 2005-6).

${ }^{2}$ Now all available in C. Grocock and I.N. Wood (eds and trans.), Abbots of Wearmouth and Jarrow (Oxford, 2013).

${ }^{3}$ Quotation from G.W. Olsen, 'From Bede to the Anglo-Saxon Presence in the Carolingian Empire', Settimane 32 (1984), pp. 305-82, at p. 314.

${ }^{4}$ R. Sharpe, 'Some Problems concerning the Organization of the Church in Early Medieval Ireland', Peritia 3 (1984), pp. 230-70, esp. 258-9; S. Foot, Monastic Life in Anglo-Saxon England c.600-900 (Cambridge, 2006), p. 125; J. Blair, The Church in Anglo-Saxon Society (Oxford, 2005), pp. 104-5. S. Wood, The Proprietary Church in the Medieval West (Oxford, 2006), ch. 5-6, investigates the complexity of 'family monasteries' during the early Middle Ages.

${ }^{5}$ Bede, Historia abbatum [hereafter: $H A$ ], ch. 11, ed. and trans. Grocock and Wood, Abbots, pp. 48-51.

${ }^{6}$ Bede, Homelia in natale S. Benedicti (Homily I. 13), 11, 14, ed. and trans. Grocock and Wood, pp. 14-15, 18-19.

${ }^{7}$ Vita Ceolfridi [hereafter: VC], ch. 16, ed. and trans. Grocock and Wood, Abbbots, pp. 94-7. ${ }^{8}$ P. Wormald, 'Bede and Benedict Biscop', in G. Bonner (ed.), Famulus Christi: Essays in Commemoration of the Thirteenth Centenary of the Birth of the Venerable Bede (London, 1976), pp. 141-69, reprinted in P. Wormald, The Times of Bede: Studies in Early English Christian Society and its Historian, ed. Stephen Baxter (Oxford, 2006), pp. 3-29 [hereafter all citations will be from the reprint].

${ }^{9}$ Bede, $H A$, ch. 11, ed. and trans. Grocock and Wood, Abbots, pp. 48-9; also VC, ch. 16, ed. and trans. Grocock and Wood, Abbots, pp. 94-5; Regula Benedicti, 64, ed. J. Neufville and 
trans. A. de Vogüé, La Régle de Saint Benoît, 2 vols (Paris, 1972), II, pp. 648-9. On the interaction of Benedictine and Gallic influences at Wearmouth-Jarrow: A. Thacker, 'The Social and Continental Background to early Anglo-Saxon Hagiography', D.Phil. thesis, University of Oxford (1977), pp. 162-70.

${ }^{10}$ H.M.R.E. Mayr-Harting, The Venerable Bede, The Rule of St Benedict, and Social Class (Jarrow, 1976).

${ }^{11}$ Foot, Monastic Life, pp. 22, 55; Thacker, 'Social and Continental Background', pp. 204-5. Bede, Epistola ad Ecgbertum episcopum, ed. and trans. Grocock and Wood, Abbots, pp. $124-61$.

${ }^{12}$ The most recent and complete discussion of this general approach is Grocock and Wood, Abbots, pp. xiii-Ixiv. See also C. Grocock, 'Separation Anxiety: Bede and Threats to Wearmouth and Jarrow', in P. Darby and F. Wallis (eds), Bede and the Future (Farnham, 2014), pp. 67-92.

${ }^{13}$ Bede, $H A$, ch. 15, ed. and trans. Grocock and Wood, Abbots, pp. 56-7: 'utrique monasterio, uel sicut rectius dicere possumus in duobus locis posito uni monasterio beatorum apostolorum Petri et Pauli, uiginti et octo annos sollerti regimine praefuit'. Also VC, ch. 16, ed. and trans. Grocock and Wood, Abbots, pp. 94-5. For discussion see I.N. Wood, 'The Foundation of Bede's Wearmouth-Jarrow', in S. DeGregorio (ed.), The Cambridge Companion to Bede (Cambridge, 2010), pp. 84-96.

${ }^{14}$ I.N. Wood, 'The Gifts of Wearmouth and Jarrow', in W. Davies and P. Fouracre (eds), The Languages of Gift in the Early Middle Ages (Cambridge, 2010), pp. 89-115.

${ }^{15}$ Bede, HA, chs 7-8, ed. and trans. Grocock and Wood, Abbots, pp. 38-43; VC, ch. 12, ed. and trans. Grocock and Wood, Abbots, pp. 90-1. 
${ }^{16}$ In general see I.N. Wood, The Most Holy Abbot Ceolfrid (Jarrow, 1995).

${ }^{17}$ Bede, $H A$, ch. 13, ed. and trans. Grocock and Wood, Abbots, pp. 52-3: 'Benedictus ... acciit abbatem Ceolfridum, quem monasterio beati Pauli apostoli praefecerat ... et eum utrique monasterio, cunctis fauentibus, atque hoc utillimum iudicantibus, praeposuit patrem'; VC, ch. 16, ed. and trans. Grocock and Wood, Abbots, pp. 94-5: 'Vnde inito cum fratribus consilio Benedictus uocauit Ceolfridum eumque utriusque monasterii abbatem constituit'. Grocock and Wood, Abbots, p. xxxiv; Wood, Proprietary Church, pp. 128-9.

${ }^{18}$ Bede, $H A$, ch. 13, ed. and trans. Grocock and Wood, Abbots, pp. 52-3: 'uirum uidelicet sibi non tam carnis necessitudine, quam uirtutum societate propinquum'.

${ }^{19}$ VC, ch. 16, ed. and trans. Grocock and Wood, Abbots, pp. 94-5: 'qui magis sibi spiritali quam carnali erat cognatione conexus'.

${ }^{20}$ Grocock and Wood, Abbots, p. xxxiii; C. Plummer, Venerabilis Bedae Opera Historica, 2 vols. (Oxford, 1896), II, p. 364. Thacker, 'Social and Continental Background', pp. 171-2, agrees.

${ }^{21}$ Wormald, 'Benedict Biscop', p. 26 n. 102; Mayr-Harting, Rule of St Benedict, p. 10.

${ }^{22}$ Wood, 'Gifts', pp. 95-6. Bede disapproved of nobles appointing their own wives to be abbesses of communities they had founded: Epistola, 12, ed. and trans. Grocock and Wood, Abbots, pp. 148-9; while his expressed dissatisfaction was with people ignorant of the monastic life taking on the position of abbot/abbess, it may have been hard for contemporaries to distinguish such situations from at Wearmouth-Jarrow where Biscop also appointed relatives, albeit ones apparently well-qualified for their positions. 
${ }^{23}$ Grocock and Wood, Abbots, p. xxxiv. The abbot's power (effectively as 'owner' of the monastery) to appoint his heir did not necessarily mean that family-members would always directly succeed: Wood, Proprietary Church, pp. 127-39.

${ }^{24}$ On the dating of both works see W. Levison, 'Bede as historian', in A.H. Thompson (ed.), Bede, his Life, Times, and Writings: Essays in Commemoration of the Twelfth Centenary of his Death (Oxford, 1935), pp. 111-51, at p. 129, for the traditional argument that Bede only wrote the HA after 725 with the VC predating that by some time, and Wood, 'Bede's Wearmouth-Jarrow', for the argument that in fact Bede was writing before Ceolfrith's hagiographer, probably no later than 717 . The traditional order of composition (if not necessarily the dating) has been recently defended by T. Major, 'Words, Wit, and Wordplay in the Latin Works of the Venerable Bede', Journal of Medieval Latin 22 (2012), pp. 185-219, at pp. $193-5$.

${ }^{25}$ Bede, $H A$, ch. 10, ed. and trans. Grocock and Wood, Abbots, pp. 46-7: 'Sed aderat et solamen, quia in loco Eosteruini uirum aeque reuertissimum ac mitissimum de monasterio eodem, Sigfridus uidelicet diaconum, electione fratrum suorum simul et coabbatis eius Ceolfridi, mox substitutum cognouit'; VC, ch. 13, ed. and trans. Grocock and Wood, Abbots, pp. 92-3: 'Pro quo fratres una cum consilio Ceolfridi abbatis Sigfridum diaconem eiusdem monasterii, mire sanctitatis uirum ..., constituere abbatem.'

${ }^{26}$ Grocock and Wood, Abbots, p. xxxiii; William, Gesta regum Anglorum, I.54.4, ed. and trans. R.A.B. Mynors, R.M. Thomson and M. Winterbottom, The History of the English Kings (Oxford, 1998), pp. 84-5: 'dum per alienas terras cursitat diu absens, subintroductum a monachis Wirensibus se inconsulto abbatem aequanimiter, immo magnanimiter tulerit, domumque reuersus parilem illi honorem in consessu.' Plummer, Opera Historica, II, p. 363, 
noted that William's phraseology 'stamps the proceeding [Sicgfrith's election] with a note of blame'.

${ }^{27}$ See n. 25 above.

${ }^{28}$ M. Gleason, 'Bede and his Fathers', Classica et Mediaevalia 45 (1994), pp. 223-38, at p. 225; Simon Coates, 'Ceolfrid: history, hagiography and memory in seventh- and eighthcentury Wearmouth-Jarrow', Journal of Medieval History 25 (1999), pp. 69-86, at pp. 71-2. ${ }^{29}$ Bede, HA, ch. 20, ed. and trans. Grocock and Wood, Abbots, pp. 70-1: 'sustulit ossa Eosteruini abbatis, quae in porticu ingressus ecclesiae beati apostoli Petri erant posita, necnon et ossa Sigfridi abbatis ac magistri quondam sui, quae foris sacrarium ad meridiem fuerant condita, et utraque in una theca sed medio pariete diuisa recludens, intus in eadem ecclesia iuxta corpus beati patris Benedicti composuit. Fecit autem haec die natalis Sigfridi ...

${ }^{30}$ Byrhtferth/Symeon, Historia regum, ch. 24, ed. T. Arnold, Symeoni monachis opera omnia, 2 vols (London, 1882-5), II, p. 22: 'Hwetbyrhtus ... qui erat discipulus abbatis Sigfridi.'

${ }^{31}$ For the importance of imitation in monastic education: J. Leclercq, 'Pedagogie et formation spirituelle du VI ${ }^{\mathrm{e}}$ au IX ${ }^{\mathrm{e}}$ siècle', Settimane 19 (1972), pp. 255-90; C. Cubitt, 'Monastic Memory and Identity in Early Anglo-Saxon England', in W.O. Frazer and A. Tyrrell (eds), Social Identity in Early Medieval Britain (London, 2000), pp. 253-76, at pp. 262-7.

${ }^{32}$ Bede, $H A$, ch. 18, ed. and trans. Grocock and Wood, Abbots, pp. 66-7: 'Huetberctus, qui a primis pueritiae temporibus eodem in monasterio ...'; VC, ch. 29, ed. and trans. Grocock and Wood, Abbots, pp. 108-9: 'Huetberctum ... Qui in monasterio eodem a prima aetate conuersatus ....' 
${ }^{33}$ Bede preached on the inadvisability of celebrating one's earthly birthday (something which apparently only Herod and Pharaoh had done in the Bible) rather than marking the days on which holy men had died: Homeliae euangelii, II.23, ed. D. Hurst, CCSL 122 (Turnhout, 1955), pp. 351-3.

${ }^{34}$ See A. Thacker, 'The Making of a Local Saint', in A. Thacker and R. Sharpe (eds), Local Saints and Local Churches in the early Medieval West (Oxford, 2002), pp. 45-73.

${ }^{35}$ Bede, $H A$, ch. 14, ed. and trans. Grocock and Wood, Abbots, pp. 54-7; VC, ch. 18, ed. and trans. Grocock and Woods, Abbots, pp. 96-7.

${ }^{36}$ É. Ó Carragáin, 'The Term Porticus and Imitatio Romae in Early Anglo-Saxon England', in H. Conrad O'Briain, A.M. d'Arcy and J. Scattergood (eds), Text and Gloss: Studies in Insular Learning and Literature Presented to Joseph Donovan Pheifer (Dublin, 1999), pp. 13-34, at p. 32.

${ }^{37}$ E.g. D.H. Farmer (trans.), Lives of the Abbots of Wearmouth and Jarrow, in The Age of Bede (London: Penguin, 1983), p. 208: 'the bones ... of Abbot Sigfrid ... which were buried in a spot just south of the sanctuary.' For sacrarium as cemetery see Plummer, Opera Historica, II, p. 155.

${ }^{38}$ Ó Carragáin, 'The Term Porticus', p. 32; C. Cubitt, 'Universal and Local Saints in AngloSaxon England', in Thacker and Sharpe (eds), Local Saints and Local Churches, pp. 423-53, at p. 436, agrees that Eosterwine and Sicgfrith were translated to Biscop's grave 'from the humbler sites of the entrance porch and the monastic cemetery' but does not comment upon this or draw attention to the possible significance of the difference between Eosterwine and Sicgfrith's original resting-places. Archaeology has confirmed that the 
cemetery at Wearmouth lay to the south of the church: Cramp et al., Monastic Sites, I, pp. $77,88$.

${ }^{39}$ Thacker, 'Making', p. 64; VC, ch. 18, ed. and trans. Grocock and Woods, Abbots, pp. 96-7: 'Sepultus est ... Benedictus in portico beati Petri, ad orientem altaris ... '. Bede, Vita sancti Cuthberti, ch. 40, ed. and trans. B. Colgrave, Two Lives of Saint Cuthbert (Cambridge, 1940), pp. 288-9; Bede, Historia ecclesiastica gentis Anglorum [hereafter: HE], III.17, V.19, ed. and trans. B. Colgrave and R.A.B. Mynors (Oxford, 1969), pp. 264-5, 528-9.

${ }^{40}$ Thacker, 'Making', p. 71.

${ }^{41}$ Bede, $H A$, ch. 14, ed. and trans. Grocock and Wood, Abbots, pp. 52-5: 'primo uenerabilis ac Deo dilectus abbas Sigfridus ... introiit in domum regni caelestis ... ac deinde adiunctis aliis mensibus quattuor ... Benedictus ... ad extrema peruenit.' Also VC, ch. 17, ed. and trans. Grocock and Wood, Abbots, pp. 96-7.

${ }^{42}$ Cramp et al., Monastic Sites, I, p. 67; but elsewhere in the same volume (p. 70) that Sicgfrith's original tomb was outside, in the monastic cemetery, seems to be accepted. ${ }^{43}$ Cubitt, 'Monastic Memory', p. 276.

${ }^{44}$ Bede, $H A$, ch. 20, ed. and trans. Grocock and Wood, Abbots, pp. 70-71: 'etiam die contigit mira Dei prouidentia ut uenerandus Christi famulus Vitmer ... excederet, et in loco ubi praedicti abbates prius sepulti fuerant, ipse qui eorum imitator fuerat, conderetur.' ${ }^{45}$ The fact that both Bede and Ceolfrith's biographer insert warnings against factionalism into their works suggests a genuine problem with internal disputes at the monastery and justifies the description of different groups at Wearmouth-Jarrow in terms of 'party': P. Hilliard, 'Sacred and Secular History in the Writings of Bede (†735)', Ph.D. thesis, University 
of Cambridge (2007), p. 95; VC, ch. 25, ed. and trans. Grocock and Wood, Abbots, pp. 104-5; Bede, $H A$, ch. 13, ed. and trans. Grocock and Wood, Abbots, pp. 52-3.

${ }^{46}$ Bede, $H A$, ch. 10, ed. and trans. Grocock and Wood, Abbots, pp. 46-7: 'uirum scientia quidem scripturarum sufficienter instructum.' Also VC, ch. 13, ed. and trans. Grocock and Wood, Abbots, pp. 92-3: 'mire sanctitatis uirum et scripturarum studiis abundanter instructum ac singulariter intentum.'

${ }^{47}$ Bede, $H A$, ch. 18, ed. and trans. Grocock and Wood, Abbots, pp. 66-7: 'in monasterio non solum regularis obseruantiae disciplinae institutus, sed et scribendi, cantandi, legendi ac docendi fuerat non parua exercitatus industria.' Also VC, ch. 29, ed. and trans. Grocock and Wood, Abbots, pp. 108-9: 'ecclesiastica simul ac monasteriali scientia imbutus.'

${ }^{48}$ Bede, HE, V.24, ed. and trans. Colgrave and Mynors, pp. 566-7: 'omnem meditandis scripturis operam dedi, atque inter obseruantium disciplinae regularis, et cotidianam cantandi in ecclesia curam, semper aut discere aut docere aut scribere dulce habui.' ${ }^{49}$ Bede lists (most of) his exegetical works at HE, V.24, ed. and trans. Colgrave and Mynors, pp. 566-9; his scriptural interpretation has attracted increasing quantities of work in recent years: see, for example, many of the contributions in S. Lebecq, M. Perrin and O. Szerwiniack (eds), Bède le Vénérable entre tradition et postérité/The Venerable Bede. Tradition and Posterity (Lille, 2005) and S. DeGregorio (ed.), Innovation and Tradition in the Writings of the Venerable Bede (Morgantown, WV, 2006). Bede emphasizes Biscop's rejection of the biological family in favour of the spiritual at Homelia in natale S. Benedicti, 11, 14, ed. and trans. Grocock and Wood, Abbots, pp. 14-15, 18-19; for the same attitude elsewhere in Bede's writings, see O. Szerwiniack, 'Frères et sœurs dans l'Histoire 
ecclésiastique du people anglais de Bède le Vénérable: De la fratrie biologique à la fratrie spirituelle', Revue bénédictine 118 (2008), pp. 239-61.

${ }^{50}$ Wormald, 'Benedict Biscop', pp. 3, 13, was aware of the possible dangers of Bede's viewpoint distorting our image of Biscop and went to some effort to argue that this had not occurred. For the Benedictine Rule in Bede's corpus: A.D.P. van der Walt, 'Reflections of the Benedictine Rule in Bede's Homiliary', Journal of Ecclesiastical History 37 (1986), pp. 36776; S. DeGregorio, 'Bede and Benedict of Nursia', in S. Baxter et al. (eds), Early Medieval Studies in Memory of Patrick Wormald (Farnham, 2009), pp. 151-63.

${ }^{51}$ Bede, $H A$, ch. 15, ed. and trans. Grocock and Wood, Abbots, pp. 60-1: 'ueteranus ac religiosus et in omni tam saeculari quam scripturarum scientia eruditus Christi famulus Vitmer'. 52 Ibid.

${ }^{53}$ Cubitt, 'Monastic Memory', pp. 256-7, argues that oblates and mature entrants to the monastic life were probably sharply differentiated by their likely levels of scriptural learning and Latin.

${ }^{54}$ Bede, $H A$, ch. 8, ed. and trans. Grocock and Wood, Abbots, pp. 40-3: 'in pistrino, in horto, in coquina, in cunctis monasterii operibus iocundus et obediens gauderet exerceri ... uel aratri gressum stiba regendo, uel ferrum malleo domando, uel uentilabrum manu concutiendo, uel aliud quid tale gerendo.'

${ }^{55}$ E.g. S. J. Coates, 'Benedict Biscop', Oxford Dictionary of National Biography, www.oxforddnb.com, 28/02/2015.

${ }^{56}$ Bede, Homelia in natale S. Benedicti, 7, 13, ed. and trans. Grocock and Wood, Abbots, pp. 10-11, 16-17: 'Ibi [in Rome] ergo eruditus in Christo, illis in partibus adtonsus, ibi est 
monasterialibus imbutus institutis ... actiones de monasteriorum quas didicerat docueratque regulis seruandis semper ... loqui et iterare delectabile habebat'; Bede, $H A$, ch. 2, ed. and trans. Grocock and Wood, Abbots, pp. 26-7: 'idonea monasticae conuersationis doctrina institutus'; VC, ch. 6, ed. and trans. Grocock and Wood, Abbots, pp. 84-5: 'Benedictus, cum esset in omnibus monasterii disciplinis instructissimus'.

${ }^{57}$ Grocock and Wood, Abbots, pp. 60 n. 150, 71 n. 187, note the perplexing importance of Witmer to Bede and the Wearmouth community. Thacker, 'Social and Continental Background', p. 211, suggests that the honour accorded Witmer sought to 'associate the monastery as closely as possible with the king and his comitatus'.

${ }^{58}$ Bede, $H A$, ch. 15, ed. and trans. Grocock and Wood, Abbots, pp. 60-1: 'Vitmer terram decem familiarum, quam ab Aldfrido rege in possessionem acceperat, in loco uillae quae Daltun nuncupatur, eidem monasterio perpetuae possessionis iure donauit.'

${ }^{59}$ Bede, $H A$, ch. 20, ed. and trans. Grocock and Wood, Abbots, pp. 70-1: 'in loco ubi praedicti abbates prius sepulti fuerant, ipse qui eorum imitator fuerat, conderetur.' Witmer only joined the community after Ceolfrith became sole abbot: Bede, $H A$, ch. 15 , ed. and trans. Grocock and Wood, Abbots, pp. 60-1.

${ }^{60}$ Bede, Explanatio apocalypseos, ed. R. Gryson, CCSL 121A (Turnhout, 2001), p. 221; Bede, Expositio actuum apostolorum, ed. M.L.W. Laistner, CCSL 121 (Turnhout, 1960), p. 3: 'expositionem apocalypseos sancti euangelistae Iohannis quam fratris nostri Eusebii rogatu tribus libris complexam mox tibi [Bede is addressing Acca] transscribendam destinaui.' F. Wallis, 'Why did Bede Write a Commentary on Revelation?', in Darby and Wallis, Bede and the Future, pp. 23-45, at pp. 28-9, argues for possible independent correspondence between Bede and Acca at an early date. 
${ }^{61}$ W. Goffart, 'Bede's History in a Harsher Climate', in DeGregorio (ed.), Innovation and Tradition, pp. 203-26, at pp. 218-20, argues that Bede's relationship with Acca was not warm. His arguments have not commanded widespread assent, but, regardless of the level of personal friendship between the two men, there can be little doubting Acca's importance as the addressee and patron of many of Bede's works.

62 Bede, In primam partem Samuhelis, ed. D. Hurst, CCSL 119 (Turnhout, 1962), p. 212: 'Huetberctum iuuenem ... post electionem fraternam sua per tuum [Bede is addressing Acca] dilectissime antistes officium benedictione confirmauit.'

${ }^{63}$ Bede, De temporum ratione, preface, ed. C.W. Jones, CCSL 123B (Turnhout, 1977), p. 265. Boniface was to later write to Hwaetberht requesting copies of some of Bede's commentaries: Epistola, 76, ed. M. Tangl, Die Briefe des Heiligen Bonifatius und Lullus, MGH, Epistolae Selectae 1 (Berlin, 1955), p. 159.

${ }^{64}$ Aenigmata Eusebii, ed. F. Glorie, CCSL 133 (Turnhout, 1968), pp. 209-71.

${ }^{65}$ A. Orchard, 'Enigma Variations: The Anglo-Saxon Riddle-Tradition', in K. O’Brien O’Keefe and A. Orchard (eds), Latin Learning and English Lore: Studies in Anglo-Saxon Literature for Michael Lapidge, 2 vols (Toronto, 2005), I, pp. 284-304.

${ }^{66} \mathrm{Dr}$ Immo Warntjes has kindly pointed out to me that early medieval computistical works were often ascribed to Eusebius of Caesarea owing to his association with the Easter cycle; however, with only two of its sixty riddles dealing with computus (see below, n. 69), this seems an unlikely explanation for the Aenigmata Eusebii.

${ }^{67}$ M.J.M. Williams, 'The Riddles of Tatwine and Eusebius', Ph.D. dissertation, University of Michigan (1974), pp. 57, 60. 
${ }^{68}$ Ibid., pp. 63, 236, 248; M. Lapidge, The Anglo-Saxon Library (Oxford, 2006), pp. 61 n. 40, 193-4, 222-3; A.C. Dionisotti, 'On Bede, Grammars, and Greek', Revue bénédictine 92 (1982), pp. 111-41.

${ }^{69}$ Aenigmanta Eusebii, XXVI (De die bissextile), XXIX (De <a>etate et saltu), ed. Glorie, pp. 236, 239; Williams, 'Riddles', p. 57.

70 That King Nechtan of the Picts wrote to Ceolfrith requesting arguments to support his decision to accept the Dionysian Easter suggests that Ceolfrith's monastery enjoyed a reputation for expertise in computus: Bede, $H E$, V.21, ed. and trans. Colgrave and Mynors, pp. 532-3.

${ }^{71}$ Williams, 'Riddles', p. 62.

${ }^{72}$ Bede, In primam partem Samuhelis, ed. Hurst, p. 212: 'Huetberctum iuuenem cui amor studiumque pietatis iam olim Eusebii cognomen indidit.'

${ }^{73}$ A. Thacker, 'Bede and the Ordering of Understanding', in DeGregorio (ed.), Innovation and Tradition, pp. 37-63, at pp. 39-40.

${ }^{74}$ M. de Jong, In Samuel's Image: Child Oblation in the Early Medieval West (Leiden, 1996), esp. pp. 219-27 on the continuing links between oblates and their families.

${ }^{75}$ It should be noted that Wearmouth-Jarrow was not unusual as a 'family monastery' in having an abbot unrelated to the original founder within a few generations: Wood, Proprietary Church, pp. 131-2, 135-6.

${ }^{76}$ Hwaetberht described Ceolfrith, in his letter to Gregory III, as 'prope iam moriturus': Bede, $H A$, ch. 19, ed. and trans. Grocock and Wood, p. 68; VC, ch. 30, ed. and trans. Grocock and Wood, p. 110.

${ }^{77}$ Cf. Gleason, 'Fathers', p. 232. 
${ }^{78}$ W. Goffart, The Narrators of Barbarian History (A.D. 550-800): Jordanes, Gregory of Tours, Bede and Paul the Deacon, $2^{\text {nd }}$ edn (Notre Dame, IN, 2005), p. 280, argues that Ceolfrith probably resigned when he did so that the succession at Wearmouth-Jarrow could be controlled internally; he even suggests (n. 206) that Hwaetberht was 'possibly [Ceolfrith's] hand-picked choice'.

${ }^{79}$ Bede, In primam partem Samuhelis, ed. Hurst, p. 212: 'Verum haec eadem mihi quies, sit tamen quies dicenda est inopinata mentis anxietas, prolixior multo quam decreueram noua circumstantium rerum mutatione prouenit maxime discessu abbatis mei reverendissimi qui post longam monasterialis curae observantiam subitus Romam adire ... non parua commissorum sibi animos et eo maiore quo improuisa conturbatione stupefecit'.

${ }^{80}$ Grocock and Wood, Abbots, pp. xxxix-xliii; A. Thacker, 'Bede, the Britons and the Book of Samuel', in Baxter, et al. (eds), Early Medieval Studies, pp. 129-47, at pp. 144-7.

${ }^{81}$ I. Wood, 'Who are the Philistines? Bede's Readings of Old Testament Peoples', in C. Gantner, R. McKitterick and S. Meeder (eds), The Resources of the Past in Early Medieval Europe (Cambridge, 2015), pp. 172-87, esp. p. 179; Thacker, 'Bede, the Britons', pp. 144-7. ${ }^{82}$ I return to this issue at greater length in my forthcoming 'Kings and Kingship in the Writings of Bede'.

${ }^{83}$ Bede, In primam partem Samuhelis, ed. Hurst, p. 212: ' Sed qui Moysi longaeuo ab humanis rebus tollendo lesum Naue in ducatum qui Eleazarum in sacerdotium Aaron patri substituit ipse prouecto aetate Ceolfrido ad beatorum apostolorum limina sancta properanti Huetberctum iuuenem ... ad regendas sacerdotio ducatuque spiritali fidelium animas abbatis uice substituit ... Redeunte temporum statu tranquilliore redir et mihi otium pariter ac delectatio mirabilia scripturae sacrae tota animae sollertis intentione scrutandi'. 
${ }^{84}$ Bede, $H A$, ch. 18, ed. and trans. Grocock and Wood, Abbots, pp. 66-7: 'Romam quoque temporibus beatae memoriae Sergii papae accurrens, et non paruo ibidem temporis spatio demoratus, quaeque sibi necessaria iudicabat, didicit, descripsit, retulit'.

${ }^{85}$ Bede, $H A$, ch. 15, ed. and trans. Grocock and Wood, Abbots, pp. 58-61; VC, ch. 20, ed. and trans. Grocock and Wood, Abbots, pp. 98-9. Goffart, Narrators, pp. 277-8, notes that it is strange that the sources from Wearmouth-Jarrow do not preserve the papal privileges; the detailed description of Ceolfrith's resignation and replacement is given priority 'as accomplished fact and precedent' over the documents.

${ }^{86}$ Grocock and Wood, Abbots, p. 66 n. 171, briefly suggest that Hwaetberht might be a candidate for author of the Vita Ceolfridi. A comparison of the Life's language with that of Hwaetberht's letter to the pope (Bede, $H A$, ch. 19, ed. and trans. Grocock and Wood, Abbots, pp. 66-9; VC, ch. 30, ed. and trans. Grocock and Wood, Abbots, pp. 108-11), and possibly (though more problematically) also that of the Aenigmata Eusebii, may prove helpful here. The suggestion that Bede himself authored the Vita Ceolfridi (Judith McClure, 'Bede and the Life of Ceolfrid', Peritia 3 (1984), pp. 71-84) seems now to be firmly scotched on stylistic grounds: Grocock and Wood, Abbots, pp. Ixiv-xcv.

${ }^{87}$ Part of this research was presented at the Leeds International Medieval Congress, July 2015. The final work has been enriched by the comments and conversation of Sarah Foot, Alan Thacker, Immo Warntjes and Charles West. All errors remain my own. 